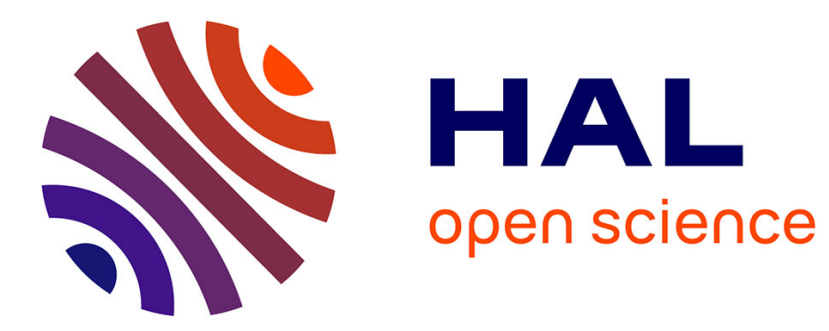

\title{
New oleanane-type saponins: Leptocarposide B-D, from Ludwigia leptocarpa (Onagraceae)
}

Florence Déclaire Mabou, David Ngnokam, Dominique Harakat, Laurence Voutquenne-Nazabadioko

\section{- To cite this version:}

Florence Déclaire Mabou, David Ngnokam, Dominique Harakat, Laurence Voutquenne-Nazabadioko. New oleanane-type saponins: Leptocarposide B-D, from Ludwigia leptocarpa (Onagraceae). Phytochemistry Letters, 2015, 14, pp.159-164. 10.1016/j.phytol.2015.10.008 . hal-03407777

HAL Id: hal-03407777

https://hal.univ-reims.fr/hal-03407777

Submitted on 28 Oct 2021

HAL is a multi-disciplinary open access archive for the deposit and dissemination of scientific research documents, whether they are published or not. The documents may come from teaching and research institutions in France or abroad, or from public or private research centers.
L'archive ouverte pluridisciplinaire HAL, est destinée au dépôt et à la diffusion de documents scientifiques de niveau recherche, publiés ou non, émanant des établissements d'enseignement et de recherche français ou étrangers, des laboratoires publics ou privés. 


\section{New oleanane-type saponins: Leptocarposides B-D from Ludwigia leptocarpa (Onagraceae)}

Florence Déclaire MABOU ${ }^{\mathrm{a}}$, David NGNOKAM ${ }^{\mathrm{a}}$, Dominique HARAKAT ${ }^{\mathrm{b}}$ and Laurence VOUTQUENNE-NAZABADIOKO

${ }^{a}$ Faculty of Science, Department of Chemistry, University of Dschang, P.O. Box 67. Dschang, Cameroon

bervice Commun d'Analyses, Institut de Chimie Moléculaire de Reims (ICMR), CNRS UMR 7312, Bat. 18 B.P. 1039, 51687 Reims Cedex 2, France

${ }^{\mathrm{c}}$ Groupe Isolement et Structure, Institut de Chimie Moléculaire de Reims (ICMR), CNRS

UMR 7312, Bat. 18 B.P. 1039, 51687 Reims Cedex 2, France 


\begin{abstract}
Three new oleanane saponins, leptocarposides B-D (1-3), were isolated from the whole plant of Ludwigia leptocarpa (Nutt) Hara, together with ten known compounds 4-13. The structures of the compounds were determined by interpretation of their spectral data, mainly HR-TOFESIMS, 1D-NMR $\left({ }^{1} \mathrm{H},{ }^{13} \mathrm{C}\right)$ and 2D-NMR $\left({ }^{1} \mathrm{H}-{ }^{1} \mathrm{H}\right.$ COSY, HSQC, HMBC, and NOESY), and by comparison with literature data. The structures of the new compounds were established as 28-O- $\beta$-D-xylopyranosyl-( $1 \rightarrow 4)-\alpha$-L-rhamnopyranosyl- $(1 \rightarrow 2)-[\alpha$-Larabinopyranosyl-( $(1 \rightarrow 3)$ ]-4- $O$-(3'-hydroxybutanoyloxy-3-hydroxybutanoyloxy)- $\beta$-Dfucopyranosylzanhic acid (1); 3- $O-\beta$-D-glucopyranosyl-28- $O$ - $\beta$-D-xylopyranosyl-( $1 \rightarrow 4)-\alpha$-Lrhamnopyranosyl-( $1 \rightarrow 2)-4-O$-(3'-hydroxybutanoyloxy-3-hydroxybutanoyloxy)- $\beta$-Dfucopyranosylmedicagenic acid (2); 3- $O$ - $\beta$-D-glucopyranosyl-(1 $\rightarrow 4)-\beta$-D-glucopyranosyl-28$O$ - $\beta$-D-xylopyranosyl-( $1 \rightarrow 4)-\alpha$-L-rhamnopyranosyl-( $1 \rightarrow 2)$-[ $\alpha$-L-arabinopyranosyl- $(1 \rightarrow 3)]-4$ $O$-(3'-hydroxybutanoyloxy-3-hydroxybutanoyloxy)- $\beta$-D-fucopyranosylzanhic acid (3).
\end{abstract}

Keywords: Ludwigia leptocarpa; Onagraceae; Triterpenoid glycoside; Bidesmoside; Leptocarposide; Structure elucidation. 


\section{Introduction}

Ludwigia leptocarpa (Nutt) Hara (Onagraceae or Oenotheraceae) is a pantropical genus that is also well represented in North America and in tropical Africa (Oziegbe and Faluyi, 2012). It is used in Nigerian folk medicine for the treatment of rheumatism and dysentery (Burkill, 1997). Previous work on this genus revealed the presence of flavonoids (Averett et al., 1990; Mabou et al., 2014), cerebrosides and triterpenoids (Mabou et al., 2014). Further investigation of the whole plant of L. leptocarpa, as part of an ongoing effort to discover new secondary metabolites of biological importance from Cameroonian medicinal plants, resulted in the isolation and characterization of three new oleanane saponins, together with ten known compounds (4-13). This paper deals with the isolation and structure elucidation of the three new saponins.

\section{Results and discussion}

Chromatography of the $n$ - $\mathrm{BuOH}$ soluble fraction of the crude $\mathrm{MeOH}$ extract of the whole plant of L. leptocarpa afforded leptocarposides B-D (1-3) and ten known compounds (4-13) which were identified as 3-O- $\beta$-D-glucopyranosyl-28- $O-\beta$-D-xylopyranosyl-( $1 \rightarrow 4)-\alpha$ L-rhamnopyranosyl- $(1 \rightarrow 2)$-[ $\alpha$-L-arabinopyranosyl-(1 $\rightarrow 3)]-4-O$-(3'-hydroxybutanoyloxy-3hydroxybutanoyloxy)- $\beta$-D-fucopyranosylzanhic acid (4) (leptocarposide A) (Mabou et al., 2014), $\beta$-D-altro-2-heptulofuranose (5) (Begbie et al., 1966; Okuda et al., 1969), 3-O- $\alpha$-D-

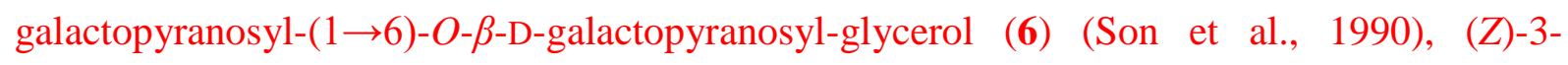
hexenyl $O$ - $\alpha$-L-arabinopyranosyl-( $1 \rightarrow 6)-\beta$-D-glucopyranosyl (7) (Noiarsa et al., 2007), phenylethyl $O$ - $\alpha$-L-arabinopyranosyl-( $(1 \rightarrow 6)-\beta$-D-glucopyranoside (8) (Ali et al., 2008), phenylmethyl $O$ - $\alpha$-L-arabinopyranosyl-( $1 \rightarrow 6)-\beta$-D-glucopyranoside (9) (Rosa et al., 1996; Ali et al., 2008), $\alpha$-D-glucopyranose (10) (Gorin and Mazurek, 1975), $\beta$-D-glucopyranose (11) (Gorin and Mazurek, 1975), $\beta$-D-fructofuranose (12) (Okada et al., 2010) and $\beta$-Dpsicopyranose (13) (Penhoat and Perlin, 1974; Valentine et al., 1981) by comparison of their spectroscopic data with literature values.

Compound 1 was obtained as a white amorphous solid which reacted positively with Liebermann-Burchard reagent. Its molecular formula was determined as $\mathrm{C}_{60} \mathrm{H}_{94} \mathrm{O}_{27}$ on the basis of its HR-TOFESIMS spectrum which showed a pseudo-molecular ion peak at $\mathrm{m} / \mathrm{z}$ 1269.5870 [M+Na] ${ }^{+}$(calcd. for $\mathrm{C}_{60} \mathrm{H}_{94} \mathrm{O}_{27} \mathrm{Na}$ 1269.5880). Its proton and carbon NMR data were similar to those of leptocarposide A (Mabou et al., 2014). Its ${ }^{1} \mathrm{H}-\mathrm{NMR}$ spectrum (Table 1) indicated the presence of six tertiary methyl groups at $\delta_{\mathrm{H}} 0.81$ (s, Me-26); 0.90 (s, Me-29); 0.98 (s, Me-30); 1.30 (s, Me-25); 1.34 (s, Me-24) and 1.41 (s, Me-27), an olefinic proton at $\delta_{\mathrm{H}}$ $5.36(\mathrm{t}, J=3.1 \mathrm{~Hz}, \mathrm{H}-12)$ and three oxygenated methine protons at $\delta_{\mathrm{H}} 4.00(\mathrm{~d}, J=3.3 \mathrm{~Hz}, \mathrm{H}-$ 
3), 4.11 (q, $J=3.3 \mathrm{~Hz}, \mathrm{H}-2)$ and 4.48 (t, $J=2.9 \mathrm{~Hz}, \mathrm{H}-16)$. Its ${ }^{13} \mathrm{C}-\mathrm{NMR}$ spectrum (Table 2) exhibited signals for six methyl groups at $\delta_{\mathrm{C}} 13.2$ (C-24), 16.2 (C-25), $16.5(\mathrm{C}-26), 23.6(\mathrm{C}-$ 30), $25.8(\mathrm{C}-27)$ and $31.9(\mathrm{C}-29)$ and two olefinic carbons at $\delta_{\mathrm{C}} 121.9(\mathrm{C}-12)$ and $143.5(\mathrm{C}-$ 13), attributable to an olean-12-ene skeleton (Mahato and Kundu, 1994; Lavaud et al.,1998; Inoue et al., 2009), in which three hydroxy groups were located at C-2 ( $\left.\delta_{\mathrm{C}} 71.1\right), \mathrm{C}-3$ (75.2) and C-16 (73.4), together with two carboxylic groups at C-23 (182.1) and C-28 (175.8). The ${ }^{1} \mathrm{H}-{ }^{1} \mathrm{H}$ COSY showed correlations between H-2 ( $\left.\delta_{\mathrm{H}} 4.11\right)$ and $\mathrm{H}-3\left(\delta_{\mathrm{H}} 4.00\right)$ and between $\mathrm{H}-$ $15 \alpha\left(\delta_{\mathrm{H}} 1.67\right), \mathrm{H}-15 \beta\left(\delta_{\mathrm{H}} 1.48\right)$, and $\mathrm{H}-16\left(\delta_{\mathrm{H}} 4.48\right)$, indicating the sites of hydroxylation. The HMBC correlations between the C-23 carboxyl carbon $\left(\delta_{\mathrm{C}} 181.1\right)$ and $\mathrm{H}-3\left(\delta_{\mathrm{H}} 4.00\right), \mathrm{H}-5$ (1.62) and Me-24 (1.34), and between the ester carbonyl at C-28 ( $\left.\delta_{\mathrm{C}} 175.8\right)$ and the oxymethine H-16 ( $\left.\delta_{\mathrm{H}} 4.48\right)$ confirmed the substitution pattern (Mahato and Kundu, 1994; Lavaud et al., 1998; Inoue et al., 2009). The 2 $\beta, 3 \beta, 16 \alpha$ configurations of the hydroxyl groups, and the $\alpha$-orientation of the $\mathrm{C}-23 \mathrm{COOH}$ at $\mathrm{C}-4$ was confirmed from the ROESY experiments. The coupling constant $(J=3.3 \mathrm{~Hz})$ between H-2 and H-3 is in accordance with the literature (Lavaud et al., 1998; Inoue et al., 2009). On this basis, the aglycone moiety of compound 1 was established as zanhic acid (2 $\beta, 3 \beta, 16 \alpha$-trihydroxyolean-12-ene-23,28-dioic acid. The shielded nature of C-28 ( $\left.\delta_{\mathrm{C}} 175.8\right)$ and C-3 (75.2) suggested a monodesmosidic saponin with an ester glycosidic linkage at C-28 (Lavaud et al., 1998; Inoue et al., 2009).

The ${ }^{1} \mathrm{H}$ and ${ }^{13} \mathrm{C}-\mathrm{NMR}$ spectra revealed the presence of four sugar units with anomeric protons at $\delta_{\mathrm{H}} 5.41$ (d, $\left.J=7.8 \mathrm{~Hz}, \mathrm{H}-1{ }^{\prime}{ }^{\prime}{ }^{\prime}\right), 5.38$ (d, $\left.J=1.5 \mathrm{~Hz}, \mathrm{H}-1{ }^{\prime},{ }^{\prime}\right), 4.51$ (d, $J=7.6 \mathrm{~Hz}, \mathrm{H}-$ 1 ',,', $)$, and $4.41\left(\mathrm{~d}, J=6.8 \mathrm{~Hz}, \mathrm{H}-1\right.$,',,', ) and the corresponding carbons at $\delta_{\mathrm{C}} 105.5(\mathrm{C}-$ 1',,’'), 104.4 (C-1',,',), 100.0 (C-1',',), and 93.7 (C-1',') (Agrawal, 1992). Two methyl carbons at $\delta_{\mathrm{C}} 15.5$ (C-6",') and 17.0 (C-6,",') indicated the presence of two 6-desoxyhexoses, and two oxymethylene carbons at $\delta_{\mathrm{C}} 65.6$ (C-5,,,',), and 65.9 (C-5,,,,',) suggested two pentoses. Analysis of COSY, TOCSY, and ROESY spectra allowed complete assignment of the spin systems of a rhamnopyranose, a fucopyranose, a xylopyranose and an arabinopyranose (Table 1). The anomeric configurations of the fucose and xylose were determined to be beta, and those of arabinose and rhamnose to be alpha from the ${ }^{3} J_{\mathrm{H} 1-\mathrm{H} 2}$ values of the anomeric protons and the chemical shifts of the anomeric carbons (Agrawal, 1992). The sugar composition was confirmed by thin layer chromatography (TLC) after hydrolysis, and the D or L-configurations were proved by gas chromatography-mass spectrometry (GC-MS) after derivatization (Mabou et al., 2014). The carbons of each monosaccharide were attributed by analysis of HSQC spectra and indicated the presence of a terminal $\beta$-D-xylopyranose, a terminal $\alpha$-L-arabinopyranose, a 4-substitued $\alpha$-L- 
rhamnopyranose $\left(\delta_{\mathrm{C}} 82.5\left(\mathrm{C}-4{ }^{\prime \prime},{ }^{\prime}\right)\right)$, and a 2,3,4-trisubstitued $\beta$-D-fucopyranose $\left(\delta_{\mathrm{C}} 72.8(\mathrm{C}\right.$ 2 '"'), $\delta_{\mathrm{C}} 80.8\left(\mathrm{C}-3{ }^{\prime \prime \prime}\right)$, and $\left.\delta_{\mathrm{C}} 73.7\left(\mathrm{C}-4^{\prime \prime \prime}\right)\right)$ (Table 2). The downfield shift of H-4"' $\left(\delta_{\mathrm{H}} 5.30\right.$ $(\mathrm{d}, J=3.5 \mathrm{~Hz}))$ suggested an esterification of the fucose at this position.

The ${ }^{1} \mathrm{H}-\mathrm{NMR}$ spectrum (Table 1) also showed two oxymethine groups at $\delta_{\mathrm{H}} 5.31(\mathrm{~m}$, $\mathrm{H}-3,,,,,,$, ) and 4.18 (m, H-3,,,,,,,') and two methyl groups at $\delta_{\mathrm{H}} 1.35(\mathrm{~d}, J=6.4 \mathrm{~Hz}, \mathrm{H}-$ 4,,,,,', ) and $1.23(\mathrm{~d}, J=6.2 \mathrm{~Hz}, \mathrm{H}-4,,,,,,$, ), suggesting the presence of two 3hydroxybutanoic acid (HBA) (Li and Doi, 1998; Mabou et al., 2014 ). In the ${ }^{13} \mathrm{C}-\mathrm{NMR}$ spectrum (Table 2), resonances of two other ester carbonyls at $\delta_{\mathrm{C}} 171.1$ and 170.3, corresponding respectively to $\mathrm{C}-1,{ }^{\prime},,,$, of $\mathrm{HBA}$ and to $\mathrm{C}-1,,,,,,$, of $\mathrm{HBA}^{\prime}$, two methyl carbons at $\delta_{\mathrm{C}} 21.9$ (HBA-C-4,,,,,,') and 18.6 (HBA'-C-4,,,,,,,'), and two oxymethine carbons at $\delta_{\mathrm{C}} 67.3$ (HBA-C-3,,,,,,') and 64.2 (HBA'-C-3,,,,,,,', confirmed the presence of two HBA units (Li and Doi, 1998; Inose et al., 1992 ; Laurençon et al., 2013; Mabou et al., 2014). The HMBC correlations observed between the ester carbonyl at $\delta_{\mathrm{C}} 170.3$ (HBA-C1',,',', and the methylene protons at $\delta_{\mathrm{H}} 2.81$ (HBA-H-2,",,', a) and 2.73 (HBA-H-2,",','b) and the oxymethine proton at $\delta_{\mathrm{H}} 5.31$ (HBA-H-3, $\left.,{ }^{\prime},{ }^{\prime}\right)$ ); and between the carbonyl at $\delta_{\mathrm{C}} 171.1$ (HBA'-C-1',,,,,',) and the two oxymethine protons at $\delta_{\mathrm{H}} 5.31$ (HBA-H-3,,,,,,') and 4.18 (HBA'-H-3,',,,,',), and the methylene protons at $\delta_{\mathrm{H}} 2.49$ (HBA'-H-2,,,,,,,'a) and 2.44 (HBA'-H-2,,,,,,, 'b) suggested that the two HBA were attached together (Inose et al., 1992 ; Laurençon et al., 2013; Mabou et al., 2014). The sequences and linkage sites of the different monosaccharide units were determined with the aid of key HMBC correlations. A correlation between the ester carbonyl at $\delta_{\mathrm{C}} 175.8$ (C-28) and the fucose anomeric proton $\left(\delta_{\mathrm{H}} 5.41\right)$ revealed the attachment of the fucose. Correlations between the Fuc-C-2'"' $\left(\delta_{\mathrm{C}} 74.1\right)$ and the rhamnose anomeric proton $\left(\delta_{\mathrm{H}} 5.38\right)$, the Fuc-C-3 ${ }^{\prime \prime},\left(\delta_{\mathrm{C}} 80.8\right)$ and the arabinose anomeric proton $\left(\delta_{\mathrm{H}} 4.41\right)$, between Rha-C-4,", $\left(\delta_{\mathrm{C}} 82.5\right)$ and the xylose anomeric proton $\left(\delta_{\mathrm{H}} 4.51\right)$, and between the ester carbonyl at $\delta_{\mathrm{C}} 170.3$ (HBA-C-1",,,',) and Fuc-H-4"', ( $\left.\delta_{\mathrm{H}} 5.30\right)$ revealed the remaining connectivity. Thus the sugar unit is $28-O-\beta$-D-xylopyranosyl-( $1 \rightarrow 4)-\alpha-$ L-rhamnopyranosyl-( $1 \rightarrow 2)$-[ $\alpha$-L-arabinopyranosyl- $(1 \rightarrow 3)]-4-O-\left(3^{\prime}\right.$-hydroxybutanoyloxy-3hydroxylbutanoyloxy)- $\beta$-D-fucopyranoside. The structure of compound $\mathbf{1}$ was also supported by the ${ }^{1} \mathrm{H}-{ }^{1} \mathrm{H}$ ROESY spectrum, which revealed correlations between Rha-H-1",', and FucH-2"', Fuc-H-3"', and Ara-H-1",',' and Xyl-H-1",', and Rha-H-4"',. Thus compound 1, leptocarposide $\mathrm{B}, \quad$ is $\quad 28-O-\beta$ - $\mathrm{D}$-xylopyranosyl- $(1 \rightarrow 4)-\alpha$-L-rhamnopyranosyl- $(1 \rightarrow 2)-[\alpha$ - $\mathrm{L}-$ arabinopyranosyl-( $1 \rightarrow 3)$ ]-4-O-(3'-hydroxybutanoyloxy-3-hydroxybutanoyloxy)- $\beta$-Dfucopyranosylzanhic acid (Fig. 1). 
Compound 2 was obtained as a white amorphous solid which reacted positively with Liebermann-Burchard reagent. Its positive HR-TOFESIMS exhibited a pseudo-molecular ion peak at $\mathrm{m} / \mathrm{z}, 1283.6044[\mathrm{M}+\mathrm{Na}]^{+}$(calcd. for $\mathrm{C}_{61} \mathrm{H}_{96} \mathrm{O}_{27} \mathrm{Na}$ 1283.6037), indicating a molecular formula $\mathrm{C}_{61} \mathrm{H}_{96} \mathrm{O}_{27}$. The ${ }^{1} \mathrm{H}$ - and ${ }^{13} \mathrm{C}$-NMR spectra were very similar to those of compound $\mathbf{1}$, except for the presence of a glucopyranose unit and the absence of the arabinopyranose unit and the hydroxyl group at C-16 ( $\delta_{\mathrm{C}} 28.8(\mathrm{C}-16) ; \delta_{\mathrm{H}} 2.07$ (m, H-16 $\left.\alpha\right), 1.65$ (m, H-16ק)). Thus the aglycone moiety of compound 2 was established as medicagenic acid, $2 \beta, 3 \beta$ dihydroxyolean-12-ene-23,28-dioic acid (Mahato and Kundu, 1994; Lavaud et al., 1998; Inoue et al., 2009, Mabou et al., 2014). The loss of the arabinopyranose unit was apparent from the shielded chemical shift of Fuc-C-3'"' $\left(\delta_{\mathrm{C}} 73.2\right)$. The anomeric proton at $\delta_{\mathrm{H}} 4.41(\mathrm{~d}, J$ $\left.=7.9 \mathrm{~Hz}, \mathrm{H}-1^{\prime}\right)$ and the corresponding anomeric carbon at $\delta_{\mathrm{C}} 103.2$ (C-1') suggested the presence of a glucopyranose moiety. Analysis of COSY, TOCSY and ROESY spectra allowed the full identification of the spin systems of all the sugars, a glucopyranose, a fucopyranose, a rhamnopyranose and a xylopyranose (Table 2). The linkage of the glucopyranosyl unit to $\mathrm{C}-3$ of the aglycone was determined by the HMBC correlation between Glc-C-1' and H-3. The chemical shifts of C-3 $\left(\delta_{\mathrm{C}} 85.2\right)$ and C-28 $\left(\delta_{\mathrm{C}} 176.7\right)$ confirmed the attachment of the sugar units to the aglycone and showed that compound 2 was a bidesmosidic saponin (Lavaud et al., 1998; Inoue et al., 2009). The sugar units were confirmed by thin layer chromatography (TLC) after hydrolysis, and the D or L-configurations were established as for compound 1 (Mabou et al., 2014). Thus, compound 2, leptocarposide $\mathrm{C}$, is $3-O-\beta$-D-glucopyranosyl-28- $O-\beta$-D-xylopyranosyl-( $1 \rightarrow 4)-\alpha$-L-rhamnopyranosyl-( $1 \rightarrow 2)$ 4-O-(3'-hydroxybutanoyloxy-3-hydroxybutanoyloxy)- $\beta$-D-fucopyranosylmedicagenic acid (Fig. 1).

Compound 3, a white amorphous solid, had a molecular formula $\mathrm{C}_{72} \mathrm{H}_{114} \mathrm{O}_{37}$, deduced from the pseudo-molecular ion peak at $\mathrm{m} / z$. $1593.6927[\mathrm{M}+\mathrm{Na}]^{+}$(calcd. for $\mathrm{C}_{72} \mathrm{H}_{114} \mathrm{O}_{37} \mathrm{Na}$ 1593.6937) in its positive HR-TOFESIMS, suggesting two additional hexopyranose units relative to compound $\mathbf{1}$. The ${ }^{1} \mathrm{H}$ - and ${ }^{13} \mathrm{C}-\mathrm{NMR}$ spectral data for the aglycone part were very similar to those of compound 1, indicating that it was zanhic acid. Its ${ }^{1} \mathrm{H}-\mathrm{NMR}$ spectrum, showed signals corresponding to two additional anomeric protons at $\delta_{\mathrm{H}} 4.47(\mathrm{~d}, J=7.8 \mathrm{~Hz}, \mathrm{H}-$ 1') and $4.43\left(\mathrm{~d}, J=7.8 \mathrm{~Hz}, \mathrm{H}-1\right.$ ' '), correlating to the corresponding anomeric carbons at $\delta_{\mathrm{C}}$ 102.9 (C-1') and 103.1 (C-1'') in the HSQC spectrum. Analysis of the COSY, TOCSY and ROESY spectra revealed the spin systems of the two new glucopyranoses, in addition to a fucopyranose, a rhamnopyranose, a xylopyranose and a arabinopyranose. An HMBC correlation between Glc'-C-1"' $\left(\delta_{\mathrm{C}}\right.$ 103.1) and Glc-H-4' $\left(\delta_{\mathrm{H}} 3.63\right)$ showed that the two 
glucopyranose units were attached together. The site of linkage of this bisaccharide moiety was determined by the HMBC correlation between Glc-C-1' $\left(\delta_{\mathrm{C}} 102.9\right)$ and $\mathrm{H}-3\left(\delta_{\mathrm{H}} 4.15\right)$. The chemical shifts of C-28 $\left(\delta_{\mathrm{C}} 175.8\right)$ and C-3 $\left(\delta_{\mathrm{C}} 85.5\right)$ confirmed that compound 3 was a bidesmosidic saponin (Lavaud et al., 1998; Inoue et al., 2009; Mabou et al., 2014). The sugar units were confirmed by thin layer chromatography (TLC) after hydrolysis, and the D or Lconfigurations were determined as for compounds 1 and 2 (Mabou et al., 2014). Thus compound 3. leptocarposide $\mathrm{D}$, is 3-O- $\beta$-D-glucopyranosyl-( $1 \rightarrow 4)-\beta$-D-glucopyranosyl-28- $O$ $\beta$-D-xylopyranosyl-(1 $\rightarrow 4)-\alpha$-L-rhamnopyranosyl-( $1 \rightarrow 2)-4-O$-(3'-hydroxybutanoyloxy-3hydroxybutanoyloxy)- $\beta$-D-fucopyranosylzanhic acid (Fig. 1).

\section{Experimental}

\subsection{General experimental procedures}

The melting points were recorded with a Reichert microscope (Reichert Technologies, Depew, New York USA) and are uncorrected. IR spectra were recorded with a Shimadzu FTIR-8400S (Shimadzu, France) spectrophotometer. ${ }^{1} \mathrm{H}(500 \mathrm{MHz})$ and ${ }^{13} \mathrm{C}(125 \mathrm{MHz}) \mathrm{NMR}$ spectra were recorded on a BRUKER Avance DRX-500 spectrometer (Bruker, Wissembourg, France) equipped with a BBFO+5 mm sonde. ${ }^{1} \mathrm{H}(600 \mathrm{MHz})$ and ${ }^{13} \mathrm{C}(150 \mathrm{MHz}) \mathrm{NMR}$ spectra were recorded on a BRUKER Avance III-600 spectrometer (Bruker, Wissembourg, France) equipped with a cryoplatform using $\mathrm{CD}_{3} \mathrm{OD}$ with TMS as the internal standard. TOFESIMS and HR-TOFESIMS experiments were performed using a Micromass Q-TOF micro instrument (Manchester, UK) with an electrospray source. The samples were introduced by direct infusion in a solution of $\mathrm{MeOH}$ at a rate of $5 \mu \mathrm{L} \mathrm{min}{ }^{-1}$. The optical rotations were measured on a Bellingham \& Stanley ADP 220 polarimeter (Bellingham + Stanley Ltd, United-Kingdom). Column chromatography was run on Merck silica gel (VWR, France ) 60 (70-230 mesh) and gel permeation on Sephadex LH-20 (VWR, France), while TLC was carried out on silica gel $\mathrm{GF}_{254}$ pre-coated plates with detection accomplished by spraying with $50 \% \mathrm{H}_{2} \mathrm{SO}_{4}$ followed by heating at $100{ }^{\circ} \mathrm{C}$ or by visualizing with a UV lamp at 254 and 365 $\mathrm{nm}$.

\subsection{Plant material}

The whole plant of Ludwigia leptocarpa was collected in Foto village (Menoua Division, Western region of Cameroon), in April 2011. Authentication was performed by Victor Nana, a botanist of the Cameroon National Herbarium, Yaoundé, where a voucher specimen $\left(\mathrm{N}^{\circ}\right.$ 38782/HNC) has been deposited.

\subsection{Extraction and isolation}


The dried whole plant of L. leptocarpa (4 kg) was extracted with $\mathrm{MeOH}$ at room temperature for 3 days, and the extract was concentrated to dryness under reduced pressure. Part of residue obtained (102 g) was suspended in water and successively extracted with ethyl acetate and $n$-butanol to obtain, after evaporation of solvent, $20 \mathrm{~g}$ and $40 \mathrm{~g}$, respectively. Part of the $n$-butanol-solute extract (30 g) was purified by silica gel column chromatography, eluting with EtOAc containing increasing $\mathrm{MeOH}(10 \%, 20 \%, 30 \%, 40 \%$, and $50 \%)$. Five sub-fractions $\left(\mathrm{G}_{1}-\mathrm{G}_{5}\right)$ were obtained. Fraction $\mathrm{G}_{2}(3.1 \mathrm{~g})$ was purified by silica gel column chromatography eluting with EtOAc-MeOH (8.5:1.5) to give compound 5 (white amorphous powder, $41 \mathrm{mg}$ ) and a mixture of compounds 7, 8 and $9(25 \mathrm{mg})$. Fractions $\mathrm{G}_{3}$ and $\mathrm{G}_{4}$ were combined and purified by silica gel column chromatography eluting with the mixture of EtOAc-MeOH- $\mathrm{H}_{2} \mathrm{O}(8: 1: 1)$ to give the compounds 6 (white amorphous powder, $30 \mathrm{mg}$ ), $\mathbf{1}$ (white amorphous solid, $38 \mathrm{mg}$ ) and 2 (white amorphous solid, $24 \mathrm{mg}$ ). Fraction $\mathrm{G}_{5}(2.5 \mathrm{~g}$ ) was purified by silica gel column chromatography eluting with EtOAc-MeOH- $\mathrm{H}_{2} \mathrm{O}(7: 2: 1)$ to give compounds 3 (white amorphous solid, $40 \mathrm{mg}$ ), 4 (white amorphous solid, $66 \mathrm{mg}$ ) and the mixture of compounds 10, 11, 12 and $\mathbf{1 3}$ (white amorphous solid, $15 \mathrm{mg}$ ).

\subsection{New compound information}

Leptocarpside B (1): white amorphous powder; ${ }^{1} \mathrm{H}$ - and ${ }^{13} \mathrm{C}-\mathrm{NMR}$ data, see Tables 1 and 2; $[\alpha]_{\mathrm{D}^{20}}-9^{\circ}\left(c\right.$ 0.15, MeOH); IR (KBr) $v_{\max }\left(\mathrm{cm}^{-1}\right): 3500-3300(\mathrm{OH}), 1750,(\mathrm{COOR}), 1710$ $(\mathrm{COOH}), 1635(\mathrm{C}=\mathrm{C}), 1670(\mathrm{C}-\mathrm{O})$; HRESIMS (positive-ion mode) $\mathrm{m} / \mathrm{z}: 1269.5870[\mathrm{M}+\mathrm{Na}]^{+}$ (calcd. for $\mathrm{C}_{60} \mathrm{H}_{94} \mathrm{O}_{27} \mathrm{Na} 1269.5880$ ).

Leptocarpside C (2): white amorphous powder; ${ }^{1} \mathrm{H}$ - and ${ }^{13} \mathrm{C}-\mathrm{NMR}$ data, see Tables 1 and 2; $[\alpha]_{\mathrm{D}}{ }^{20}+5^{\circ}\left(c\right.$ 0.68, MeOH); IR (KBr) $v_{\max }\left(\mathrm{cm}^{-1}\right): 3500-3300(\mathrm{OH}), 1760,(\mathrm{COOR}), 1710$ $(\mathrm{COOH}), 1640(\mathrm{C}=\mathrm{C}), 1656(\mathrm{C}-\mathrm{O})$; HRESIMS (positive-ion mode) $\mathrm{m} / z: 1283.6044[\mathrm{M}+\mathrm{Na}]^{+}$ (calcd. for $\mathrm{C}_{61} \mathrm{H}_{96} \mathrm{O}_{27} \mathrm{Na}$ 1283.6037).

Leptocarpside D (3): white amorphous powder; ${ }^{1} \mathrm{H}$ - and ${ }^{13} \mathrm{C}-\mathrm{NMR}$ data, see Tables 1 and 2; $[\alpha]_{\mathrm{D}}{ }^{20}-2$ (c 0.18, MeOH); IR (KBr) $v_{\max }\left(\mathrm{cm}^{-1}\right): 3500-3300(\mathrm{OH}), 1750,(\mathrm{COOR}), 1710$ $(\mathrm{COOH}), 1630(\mathrm{C}=\mathrm{C}), 1650(\mathrm{C}-\mathrm{O})$; HRESIMS (positive-ion mode) $\mathrm{m} / \mathrm{z}: 1593.6927[\mathrm{M}+\mathrm{Na}]^{+}$ (calcd. for $\mathrm{C}_{72} \mathrm{H}_{114} \mathrm{O}_{37} \mathrm{Na} 1593.6937$ ).

\subsection{Acid hydrolysis and determination of the absolute configurations of the monosaccharide}

Compounds 1-3 (each, $10 \mathrm{mg}$ ) were heated individually in $1 \mathrm{M} \mathrm{HCl}$ (dioxane- $\mathrm{H}_{2} \mathrm{O}, 1: 1,2 \mathrm{~mL}$ ) at $100{ }^{\circ} \mathrm{C}$ for $2 \mathrm{~h}$. After removal of the dioxane, the solutions were extracted with EtOAc (2 $\mathrm{mL}$ x 3). The remaining aqueous layers, containing the monosaccharides, were concentrated under reduced pressure to dryness. The residues were dissolved in pyridine $(0.1 \mathrm{~mL})$, to which 
0.1 M L-cysteine methyl ester hydrochloride in pyridine $(0.20 \mathrm{~mL})$ was added, and heated at $60{ }^{\circ} \mathrm{C}$ for $2 \mathrm{~h}$, dried in vacuo, and trimethylsilylated with hexamethyldisilazanetrimethylchlorosilane $(0.2 \mathrm{~mL})$ at $60{ }^{\circ} \mathrm{C}$ for $2 \mathrm{~h}$. Each mixture was partitioned between $n$ hexane and $\mathrm{H}_{2} \mathrm{O}(0.4 \mathrm{~mL})$ and the $n$-hexane was subjected to GC-MS analysis. The absolute configurations of the monosoccharides were identified as D-fucose, D-xylose, L-arabinose and L-rhamnose in compound 1; D-glucose, D-fucose, D-xylose and L-rhamnose in compound 2 and D-glucose, D-fucose, D-xylose, L-arabinose and L-rhamnose in compound 3, by comparison of the derivative retention times with literature values (Zheng, et al., 2007) and with authentic samples $(10.31,7.75,6.32,6.36$ and 7.52 , respectively).

\section{References}

Agrawal, P.K., 1992. NMR spectroscopy in the structural elucidation of oligosaccharides and glycosides. Phytochemistry 31, 3307-3330.

Ali, Z., Fronczek, R.F., Khan, A.I., 2008. Phenylalkanoids and monoterpene analogues from the Roots of Rhodiola rosea. Planta Med. 74, 178-181.

Averett, J.E., Zardini, E.M. Hoch, P.C., 1990. Flavonoid systematic of ten sections of Ludwigia (Onagraceae). Biochem. Syst. Ecol. 18, 529-532.

Begbie, R. and Richtmyer K.A., 1966. The isolation of some heptoses, heptuloses, octuloses, and nonuloses from Primula officinalis Jacq. Carbohydr. Res. 2, 272-288.

Brundish, D.E. and Baddiley, J. 1968. Synthesis of glucosylglycerols and diglucosylglycerols and their identification in small amounts. Carbohydr. Res. 8, 308-316.

Burkill, H.M., 1997. The useful plants of West Tropical Africa. Roy. Bot. Gard. p 969.

Cateni, F., Zilic, J., Zacchigna, M., 2008. Isolation and structure elucidation of cerebrosides from Euphorbia platyphyllos L. Sci. Pharm. 76, 451-469.

Gorin, P.A.J and Mazurek, M., 1975. Further studies on the assignment of signals in ${ }^{13} \mathrm{C}$ magnetic resonance spectra of aldoses and derivatives methyl glycosides. Can. $J$. Chem. 53, 1212-1223.

Herve du Penhoat, P.C.M. and Perlin, A.S. 1974. A carbon-13 N.M.R. Spectral study of Dpsicose: Anomeric and ring-form equilibria of solutions of 2-hexuloses. Carbohydr. Res. 36, 111-120.

Inose, Y., Miyase, T., Ueno, A., 1992. Studies on the constituents of Solidago virgaurea L. II. Structures of solidago-saponins X-XX. Chem. Pharm. Bull. 40, 946-953. 
Inoue, M., Ohtani, K., Kasai, R., Okukubo, M., Andriantsiferana, M., Yamasaki, K., Koike. T., 2009. Cytotoxic 16-ß3-[(D-xylopyranosyl)oxy]oxohexadecanyl triterpene glycosides from a Malagasy plant, Physena sessiliflora. Phytochemistry 70, 1195-1202.

Laurençon, L., Sarrazin, E., Chevalier, M., Prêcheur, I., Herbette, G., Fernandez, X., 2013. Triterpenoid saponins from the aerial parts of Solidago virgaurea alpestris with inhibiting activity of Candida albicans yeast-hyphal conversion. Phytochemistry 86, 103-111.

Lavaud, C., Voutquenne, L., Massiot, G., Le Men-Olivier, L., Das, B.C., Laprevote, O., Serani, L., Delaude, C., Bechi, M., 1998. Saponins from the stem bark of Filicium decipiens. Phytochemistry 47,441-449.

Li, J., Uzawa, J., Doi, Y., 1998. Conformational analysis of oligomers of $(R)$-3-hydroxy butanoic acid in solutions by ${ }^{1} \mathrm{H}$ NMR spectroscopy. Bull. Chem. Soc. Jpn. 71, 16831689.

Mabou, F.D., Foning, T.P.L., Ngnokam, D., Harakat, D., Voutquenne-Nazabadioko, L., 2014. Leptocarposide: a new triterpenoid glycoside from Ludwigia leptocarpa (Onagraceae). Magn. Reson. Chem. 52, 32-36.

Mahato, S. B., Kundu, A. P., 1994. ${ }^{13}$ C NMR spectra of pentacyclic triterpenoids. A compilation and some salient features. Phytochemistry 37, 1517-1575.

Noiarsa, P., Yu, Q., Matsunami, K., Otsuka, H., Ruchirawat, S., Kanchanapoom, T., 2007. (Z)-3-Hexenyl diglycosides from Spermacoce laevis Roxb. J. Nat. Med. 61, 406-409.

Okada, H., Fukushi, E., Yamamori, A., Kawazoe, N., Onodera, S., Kawabata, J. and Shiomi, N. 2010. Novel fructopyranose ologosacharides isolated from fermented beverage of plant extract. Carbohydr. Res. 345, 414-418.

Okuda, T., Osaki, K. and Taga, T. 1969. $\alpha$-coriofuranose: conformationally unfavoured structure in the crystalline state and rapid mutarotation of coriose. J. Chem. Soc. Chem. Comm. 15, 851-852.

Oziegbe, M., Faluyi, J.L., 2012. Reproductive biology of Ludwigia leptocarpa and L. adscendans subsp. Diffusa in Ile Ife, Nigeria. Turk J. Bot. 36, 162-173.

Rosa, D.S., Giulio, D.A., Tommonaro, G., 1996. Aliphatic and aromatic glycosides from the cell cultures of Lycopersicon esculentum. Phytochemistry, 42, 1031-1034.

Son, B.W., 1990. Glycolipids from Gracilaria verrucosa. Phytochemistry, 29, 307-309.

Sridhar, R.A., Merugu, R., Atthapu, T., 2013. A New Triterpene from ludwigia hyssopifolia (G.Don) Exell. Int. J. Chem. Tech. Res. 5, 342-346. 
Tiejun, L., Tao, X., Xiaochun, W., Daxiang, L., Xiaoyi, W., 2006. Cerebrosides from the roots of Serratula chinensis. Molecules 11, 677-683.

Valentine, K.M., Doner, L.W. and Pfeffer P.E. 1981. ${ }^{13}$ C-NMR resonance assignment of psicose by the differential isotope-shift technique. Carbohydr. Res. 96, 293-298.

Zheng, Q., Li, W., Han, L., Koike, K., 2007. Pancreatic lipase-inhibiting triterpenoid saponins from Gypsophila oldhamiana. Chem. Pharm. Bull. 55, 646-650. 
Table 1

${ }^{1} \mathrm{H}$ NMR spectral data of compounds 1-3 (MeOD, $\left.600 \mathrm{MHz}\right)$

\begin{tabular}{|c|c|c|c|c|c|c|c|}
\hline \multirow{2}{*}{$\mathrm{N}^{\circ}$} & \multicolumn{3}{|c|}{ Saponins } & \multirow{2}{*}{$\mathrm{N}^{\circ}$} & \multicolumn{3}{|c|}{ Saponins } \\
\hline & 1 & 2 & 3 & & 1 & 2 & 3 \\
\hline \multirow[t]{2}{*}{1} & $1.27(\mathrm{~m})$ & $1.28(\mathrm{~m})$ & $1.30(\mathrm{~m})$ & Fuc & & & \\
\hline & $2.14(\mathrm{dt}, 14.4,2.5)$ & $2.13(\mathrm{t}, 6.1)$ & $2.15(\mathrm{dm}, 13.2)$ & $1,$, & $5.41(\mathrm{~d}, 7.8)$ & $5.41(\mathrm{~d}, 7.9)$ & $5.41(\mathrm{~d}, 7.9)$ \\
\hline \multirow[t]{2}{*}{2} & $4.11(\mathrm{q}, 3.3)$ & $4.32(\mathrm{~m})$ & $4.31(\mathrm{q}, 3.4)$ & $2 "$, & 3.94 (dd, 9.4, & $3.79(\mathrm{~m})$ & $3.94(\mathrm{dd}, 9.2,7.9)$ \\
\hline & & & & & $7.8)$ & & \\
\hline \multirow[t]{2}{*}{3} & $4.00(\mathrm{~d}, 3.3)$ & $4.12(\mathrm{~m})$ & $4.15(\mathrm{~d}, 3.4)$ & $3, "$ & $4.03(\mathrm{dd}, 9.4$, & $3.92(\mathrm{~m})$ & $4.03(\mathrm{dd}, 9.2,3.6)$ \\
\hline & & & & & $3.5)$ & & \\
\hline 4 & - & - & - & $4 "$, & $5.30(\mathrm{~d}, 3.5)$ & $5.12(\mathrm{~d}, 3.7)$ & $5.30(\mathrm{~d}, 3.6)$ \\
\hline 5 & $1.62(\mathrm{~m})$ & $1.64(\mathrm{~m})$ & $1.64(\mathrm{~m})$ & 5, & $3.87(\mathrm{~m})$ & $3.87(\mathrm{~m})$ & $3.88(\mathrm{~m})$ \\
\hline \multirow[t]{2}{*}{6} & $1.25(\mathrm{~m})$ & $1.22(\mathrm{~m})$ & $1.28(\mathrm{~m})$ & $6 "$, & $1.08(\mathrm{~d}, 6.5)$ & $1.09(\mathrm{~d}, 6.3)$ & $1.08(\mathrm{~d}, 6.4)$ \\
\hline & $1.62(\mathrm{~m})$ & $1.63(\mathrm{~m})$ & $1.60(\mathrm{~m})$ & & & & \\
\hline \multirow[t]{2}{*}{7} & $1.40(\mathrm{~m})$ & $1.39(\mathrm{~m})$ & $1.39(\mathrm{~m})$ & Rha & & & \\
\hline & $1.59(\mathrm{dd}, 11.6,4.2)$ & $1.55(\mathrm{~m})$ & $1.61(\mathrm{~m})$ & $1,,$, & $5.38(\mathrm{~d}, 1.5)$ & 5.40 (brs) & $5.38(\mathrm{~d}, 1.6)$ \\
\hline \multirow[t]{2}{*}{8} & - & - & - & $2,$, & 3.97 (dd, 8.1, & $3.96(\mathrm{~m})$ & $3.98(\mathrm{dd}, 8.9,1.6)$ \\
\hline & & & & & $1.5)$ & & \\
\hline \multirow[t]{2}{*}{9} & $1.67(\mathrm{~m})$ & $1.61(\mathrm{~m})$ & $1.69(\mathrm{~m})$ & $3,$, & $3.83(\mathrm{dd}, 9.1$, & $3.84(\mathrm{~m})$ & $3.83(\mathrm{~m})$ \\
\hline & & & & & $8.1)$ & & \\
\hline 10 & - & - & - & $4,$, & $3.57(\mathrm{t}, 9.1)$ & $3.50(t, 9.3)$ & $3.55(t, 9.4)$ \\
\hline \multirow[t]{2}{*}{11} & $1.97(\mathrm{~m})$ & $1.63(\mathrm{~m})$ & $1.95(\mathrm{~m})$ & $5,$, & $3.82(\mathrm{~m})$ & $3.83(\mathrm{~m})$ & $3.81(\mathrm{~m})$ \\
\hline & $2.04(\mathrm{~m})$ & $2.07(\mathrm{~m})$ & $2.03(\mathrm{~m})$ & & & & \\
\hline 12 & $5.36(\mathrm{t}, 3.1)$ & $5.30(\mathrm{t}, 3.5)$ & $5.36(\mathrm{t}, 4.9)$ & $6, "$, & $1.35(\mathrm{~d}, 6.4)$ & $1.35(\mathrm{~d}, 6.4)$ & $1.35(\mathrm{~d}, 6.3)$ \\
\hline \multirow[t]{2}{*}{13} & - & - & - & Xyl & & & \\
\hline & & & & $1,,,$, & $4.51(\mathrm{~d}, 7.6)$ & $4.43(\mathrm{~d}, 7.5)$ & $4.49(\mathrm{~d}, 7.4)$ \\
\hline \multirow[t]{2}{*}{14} & - & - & - & $2, \%$, & $3.21(\mathrm{dd}, 8.9$ & $3.22(\mathrm{~m})$ & $3.26(\mathrm{dd}, 9.5,6.3)$ \\
\hline & & & & & 7.6) & & \\
\hline \multirow[t]{2}{*}{15} & $1.48(\mathrm{dd}, 11.8,2.8)$ & $1.37(\mathrm{~m})$ & $1.47(\mathrm{dd}, 11.3,4.1)$ & $3,,,$, & $3.25(\mathrm{~m})$ & $3.30(\mathrm{~m})$ & $3.30(t, 9.5)$ \\
\hline & $1.67(\mathrm{dm}, 11.8)$ & $1.63(\mathrm{~m})$ & $1.68(\mathrm{dm}, 11.3)$ & & & & \\
\hline \multirow[t]{2}{*}{16} & $4.48(\mathrm{t}, 2.9)$ & $1.65(\mathrm{~m})$ & $4.49(\mathrm{t}, 2.5)$ & $4,,,$, & $3.52(\mathrm{~m})$ & $3.50(\mathrm{~m})$ & $3.52(\mathrm{~m})$ \\
\hline & & $2.07(\mathrm{~m})$ & & & & & \\
\hline \multirow[t]{3}{*}{17} & - & - & - & $5,,$, & $3.20(\mathrm{t}, 10.6)$ & $3.19(\mathrm{t}, 10.8)$ & $3.21(\mathrm{t}, 11.5)$ \\
\hline & & & & & $3.88(\mathrm{dd}, 11.4$ & $3.85(\mathrm{~m})$ & $3.86(\mathrm{~m})$ \\
\hline & & & & & $5.2)$ & & \\
\hline \multirow[t]{2}{*}{18} & $2.95(\mathrm{dd}, 14.2,3.9)$ & $2.84(\mathrm{~m})$ & $2.95(\mathrm{dd}, 13.8,3.9)$ & Ara & & & \\
\hline & & & & $1,,,,$, & $4.41(\mathrm{~d}, 6.8)$ & - & $4.42(\mathrm{~d}, 6.6)$ \\
\hline \multirow[t]{2}{*}{19} & $1.23(\mathrm{~m})$ & $1.16(\mathrm{~m})$ & $1.09(\mathrm{dd}, 13.8,3.9)$ & $2, \cdot,,$, & 3.56 (dd, 8.7, & - & $3.55(\mathrm{~m})$ \\
\hline & $2.32(\mathrm{t}, 13.8)$ & $1.76(\mathrm{~m})$ & $2.31(\mathrm{t}, 13.8)$ & & $6.8)$ & & \\
\hline 20 & - & - & - & $3,,,$, & $3.53(\mathrm{~m})$ & - & $3.52(\mathrm{t}, 2.1)$ \\
\hline \multirow[t]{2}{*}{21} & $1.21(\mathrm{~m})$ & $1.27(\mathrm{~m})$ & $1.20(\mathrm{~m})$ & $4,,,,$, & $3.80(\mathrm{~m})$ & - & $3.80(\mathrm{~m})$ \\
\hline & $1.97(\mathrm{~m})$ & $1.42(\mathrm{~m})$ & $1.96(\mathrm{~m})$ & & & & \\
\hline \multirow[t]{2}{*}{22} & $1.82(\mathrm{dd}, 14.4,4.5)$ & $1.63(\mathrm{~m})$ & $1.80(\mathrm{~m})$ & $5,,,,$, & $3.53(\mathrm{dd}, 11.6$ & - & $3.53(\mathrm{~m})$ \\
\hline & $1.97(\mathrm{~m})$ & $1.74(\mathrm{~m})$ & $1.96(\mathrm{~m})$ & & 1.4) & & $3.85(\mathrm{~m})$ \\
\hline
\end{tabular}


$3.84(\mathrm{dd}, 11.6$,

$3.5)$

23

24

$1.34(\mathrm{~s})$

$25 \quad 1.30(\mathrm{~s})$

$26 \quad 0.81(\mathrm{~s})$

$27 \quad 1.41(\mathrm{~s})$

28

$29 \quad 0.90(\mathrm{~s})$

30

0.98 (s)

\begin{abstract}
$1.39(\mathrm{~s}) \quad 1.37(\mathrm{~s})$
\end{abstract}
$1.30(\mathrm{~s}) \quad 1.30(\mathrm{~s})$

$0.81(\mathrm{~s}) \quad 0.80(\mathrm{~s})$

$1.40(\mathrm{~s}) \quad 1.40(\mathrm{~s})$

$-$

$\begin{array}{ll}0.90(\mathrm{~s}) & 0.90(\mathrm{~s}) \\ 0.96(\mathrm{~s}) & 0.98(\mathrm{~s})\end{array}$

$\begin{array}{ll}0.90(\mathrm{~s}) & 0.90(\mathrm{~s}) \\ 0.96(\mathrm{~s}) & 0.98(\mathrm{~s})\end{array}$

Glc

1 ,

2 ,

3, -

4,

5 ,

6' -

Glc

1 ,'

2,

$$
3 \text {, }
$$$$
4 \text {, }
$$

5 ,

6,

\section{HBA}

$1,,,,,$,

$2,,,,,$,

$2.73(\mathrm{dd}, 16.1$,

5.7)

5.6)

$2.73(\mathrm{dd}, 16.0,5.8)$

2.81 (dd, 16.1, 2.84 (dd, 16.1,

7.3) 7.3)

$\begin{array}{llll}3,,,,,,, & 5.31(\mathrm{~m}) & 5.30(\mathrm{~m}) & 5.31(\mathrm{~m}) \\ 4,,,,,,, & 1.35(\mathrm{~d}, 6.2) & 1.30(\mathrm{~m}) & 1.35(\mathrm{t}, 6.2) \\ \text { HBA', } & & & \\ 1,,,,,,, & - & - & - \\ 2,,,,,,,, & 2.44(\mathrm{dd}, 15.0, & 2.38(\mathrm{dd}, 15.0, & 2.5(\mathrm{dd}, 14.8, \\ & 5.1) & 5.3) & 2.61(\mathrm{dd}, 14.8, \\ & 2.49(\mathrm{dd}, 15.0, & 2.44(\mathrm{dd}, 15.0, & \\ & 7.3) & 7.5) & \\ 3,,,,,,,, & 4.18(\mathrm{~m}) & 4.16(\mathrm{~m}) & 4.18(\mathrm{~m}) \\ 4,,,,,,,, & 1.23(\mathrm{~d}, 6.1) & 1.22(\mathrm{~d}, 6.1) & 1.23(\mathrm{~d}, 6.2)\end{array}$

$4.43(\mathrm{~d}, 7.8)$

3.24 (dd, 9.0, 7.8)

$3.39(\mathrm{t}, 9.0)$

$3.34(\mathrm{~m})$

$3.34(\mathrm{~m})$

$2.82(\mathrm{dd}, 16.0,7.4)$

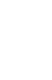


Table 2

${ }^{13} \mathrm{C}$ NMR spectral data of compounds $\mathbf{1 - 3}(\mathrm{MeOD}, 150 \mathrm{MHz})$

\begin{tabular}{|c|c|c|c|c|c|c|c|}
\hline \multirow{2}{*}{$\mathrm{N}^{\circ}$} & \multicolumn{3}{|c|}{ Saponins } & \multirow{2}{*}{$\mathrm{N}^{\circ}$} & \multicolumn{3}{|c|}{ Saponins } \\
\hline & 1 & 2 & 3 & & 1 & 2 & 3 \\
\hline 1 & 44.4 & 43.6 & 43.5 & Fuc 1,, & 93.7 & 93.7 & 93.6 \\
\hline 2 & 71.1 & 69.8 & 70.0 & 2, & 72.1 & 73.2 & 72.9 \\
\hline 3 & 75.2 & 85.2 & 85.6 & 3, & 80.8 & 73.2 & 80.8 \\
\hline 4 & 53.1 & 52.5 & 52.7 & $4 "$, & 73.7 & 73.1 & 73.7 \\
\hline 5 & 51.5 & 51.8 & 51.8 & 5, & 69.8 & 69.7 & 69.8 \\
\hline 6 & 20.7 & 20.4 & 20.5 & $6, "$ & 15.5 & 15.2 & 15.4 \\
\hline 7 & 32.6 & 32.4 & 32.5 & Rha 1",, & 100.0 & 100.1 & 100.2 \\
\hline 8 & 39.8 & 39.8 & 39.9 & $2,,$, & 70.4 & 70.4 & 70.4 \\
\hline 9 & 47.1 & 47.1 & 47.1 & $3,,$, & 70.7 & 70.8 & 70.8 \\
\hline 10 & 36.1 & 36.0 & 36.0 & $4,,$, & 82.5 & 83.7 & 82.9 \\
\hline 11 & 23.3 & 22.8 & 23.3 & $5,,$, & 67.6 & 67.5 & 67.7 \\
\hline 12 & 121.9 & 122.2 & 122.0 & $6,,$, & 17.0 & 16.9 & 17.0 \\
\hline 13 & 143.5 & 143.6 & 143.5 & Xyl 1',,, & 105.5 & 106.1 & 105.6 \\
\hline 14 & 41.5 & 41.4 & 41.6 & $2,,,$, & 74.7 & 74.9 & 74.8 \\
\hline 15 & 35.0 & 24.6 & 35.1 & $3,,,$, & 76.9 & 77.0 & 77.0 \\
\hline 16 & 73.4 & 28.8 & 73.4 & $4, ",$, & 69.5 & 69.7 & 69.5 \\
\hline 17 & 48.9 & 46.7 & 48.9 & $5,,,$, & 65.6 & 65.9 & 65.9 \\
\hline 18 & 40.9 & 41.8 & 40.9 & Ara 1,, ,, , & 104.4 & - & 104.4 \\
\hline 19 & 46.8 & 46.8 & 46.8 & $2,,,,$, & 70.9 & - & 71.1 \\
\hline 20 & 29.4 & 29.1 & 29.1 & $3,,,,$, & 73.7 & - & 73.0 \\
\hline 21 & 35.2 & 35.1 & 35.1 & $4,,,,$, & 68.2 & - & 68.2 \\
\hline 22 & 30.5 & 30.1 & 29.9 & $5,,,,$, & 65.9 & - & 65.6 \\
\hline 23 & 182.1 & 183.2 & 183.6 & Glc 1' & - & 103.2 & 102.9 \\
\hline 24 & 13.2 & 13.0 & 13.4 & 2 ' & - & 73.9 & 73.7 \\
\hline 25 & 16.2 & 15.9 & 16.1 & $3^{\prime}$ & - & 76.3 & 74.7 \\
\hline 26 & 16.5 & 16.7 & 16.5 & $4^{\prime}$ & - & 69.9 & 78.4 \\
\hline 27 & 25.8 & 24.9 & 25.9 & 5 , & - & 76.3 & 74.9 \\
\hline 28 & 175.8 & 176.7 & 175.8 & 6 ' & - & 60.9 & 60.9 \\
\hline 29 & 31.9 & 32.1 & 31.9 & Gle 1', & - & - & 103.1 \\
\hline \multirow[t]{11}{*}{30} & 23.6 & 23.3 & 23.6 & 2 ' & - & - & 73.5 \\
\hline & & & & 3, & - & - & 76.4 \\
\hline & & & & $4 "$, & - & - & 69.9 \\
\hline & & & & 5 " & - & - & 76.7 \\
\hline & & & & $6 "$ & - & - & 60.1 \\
\hline & & & & HBA 1,,,,,, & 170.3 & 169.9 & 170.1 \\
\hline & & & & $2,,,,$, & 40.0 & 39.9 & 39.8 \\
\hline & & & & $3,,,,$, & 67.3 & 67.4 & 67.5 \\
\hline & & & & $4,,,,,$, & 18.6 & 18.7 & 18.6 \\
\hline & & & & HBA' 1,,,,,,, & 171.1 & 170.4 & 171.4 \\
\hline & & & & $2,,,,,,$, & 43.7 & 43.6 & 43.6 \\
\hline
\end{tabular}


$3,,,,, \quad 64.2 \quad 64.1 \quad 64.3$

$4,,,,,, \quad 21.9 \quad 21.9 \quad 21.9$ 

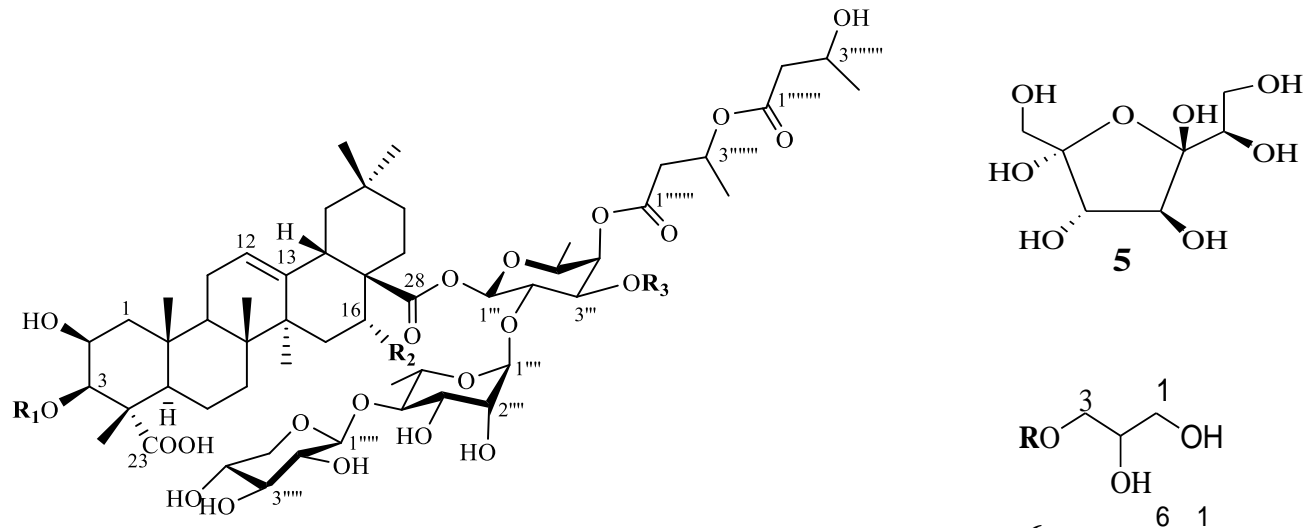

\begin{tabular}{|c|c|c|}
\hline 0 & $\begin{array}{l}\mathbf{R}_{1} \\
\mathbf{H}\end{array}$ & $\begin{array}{l}\mathbf{R}_{2} \\
\mathrm{OH}\end{array}$ \\
\hline 2 & Gle & H \\
\hline 3 & Gle-Glc & $\mathrm{OH}$ \\
\hline & Glc & $\mathbf{O H}$ \\
\hline
\end{tabular}
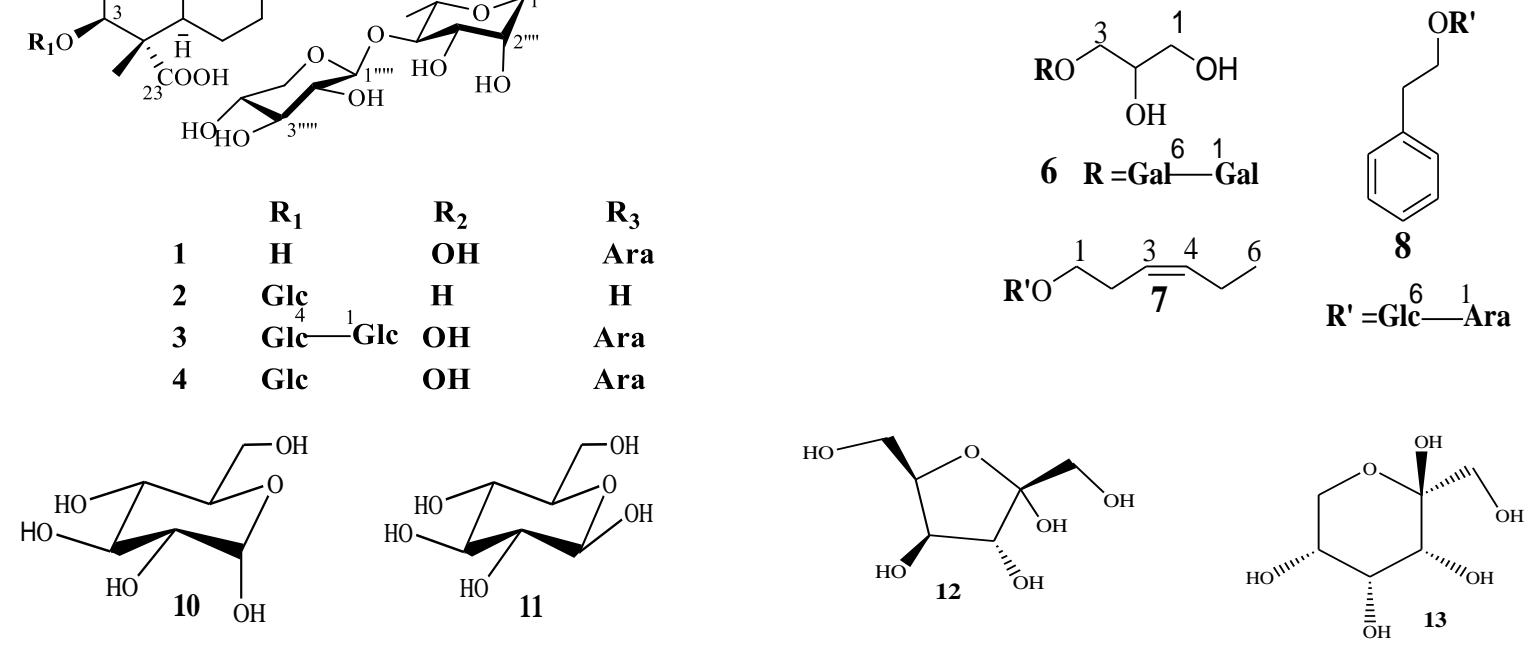

Fig. 1. Structures of compounds 1-13 isolated from $n-\mathrm{BuOH}$ soluble extract of $L$. leptocarpa. 